In the House of the Law 



\title{
In the House of the Law
}

Gender and Islamic Law in

Ottoman Syria and Palestine

\author{
Judith E. Tucker
}

UNIVERSITY OF CALIFORNIA PRESS

Berkeley Los Angeles London 
University of Califomia Press

Berkeley and Los Angeles, California

University of California Press, Ltd.

London, England

(C) 1998 by

The Regents of the University of California

\section{Library of Congress Cataloging-in-Publication Data}

'Tucker, Judith E.

In the house of the law : gender and Islamic law in

Ottoman Syria and Palestine / Judith E. Tucker.

p. cm.

Includes bibliographical references and index.

ISBN 0-520-2 1039-5 (cloth : alk. paper)

I. Women-Legal status, laws, etc.-Syria-History.

2. Women-Legal status, laws, etc.-Palestine-History.

3. Women-Legal status, laws, etc. (Islamic law)

4. Turkey-History-Ottoman Empire, I $288-1918$.

5. Women-Syria-Social conditions. 6. Women-

Palestine-Social conditions. I. Title.

$\mathrm{KMCI}_{45}$.W64 $\mathrm{T}_{3}{ }_{1998}$

305.42'09569I-dc2 I

Chapter 2 of this book was previously published in a different form as "Muftis and Matrimony: Islamic Law and Gender in Ottoman Syria and Palestine," Islamic Law and Society, I, 3, 265-300 (c) Brill Publishers.

Printed in the United States of America 98765432 I

The paper used in this publication is both acid-free and totally chlorine-free (TCF). It meets the minimum requirements of American Standard for Information Sciences-Permanence of Paper for Printed Library Materials, ANSI Z39.48-r984. 
For Sharif 
